\title{
The Role of School Management Towards Staff Motivation for Effective Performance in Nepal: During the COVID-19
}

\author{
${ }^{1}$ Manoj Kumar Chaudhary, Ph. D, ${ }^{2}$ Rajesh Kumar Chaudhary \\ ${ }^{1}$ Associate Professor, Central Department of Management, TU, Nepal \\ ${ }^{2}$ DAV Business School, Purbanchal University, Nepal \\ 1manoj.cdmtu@gmail.com
}

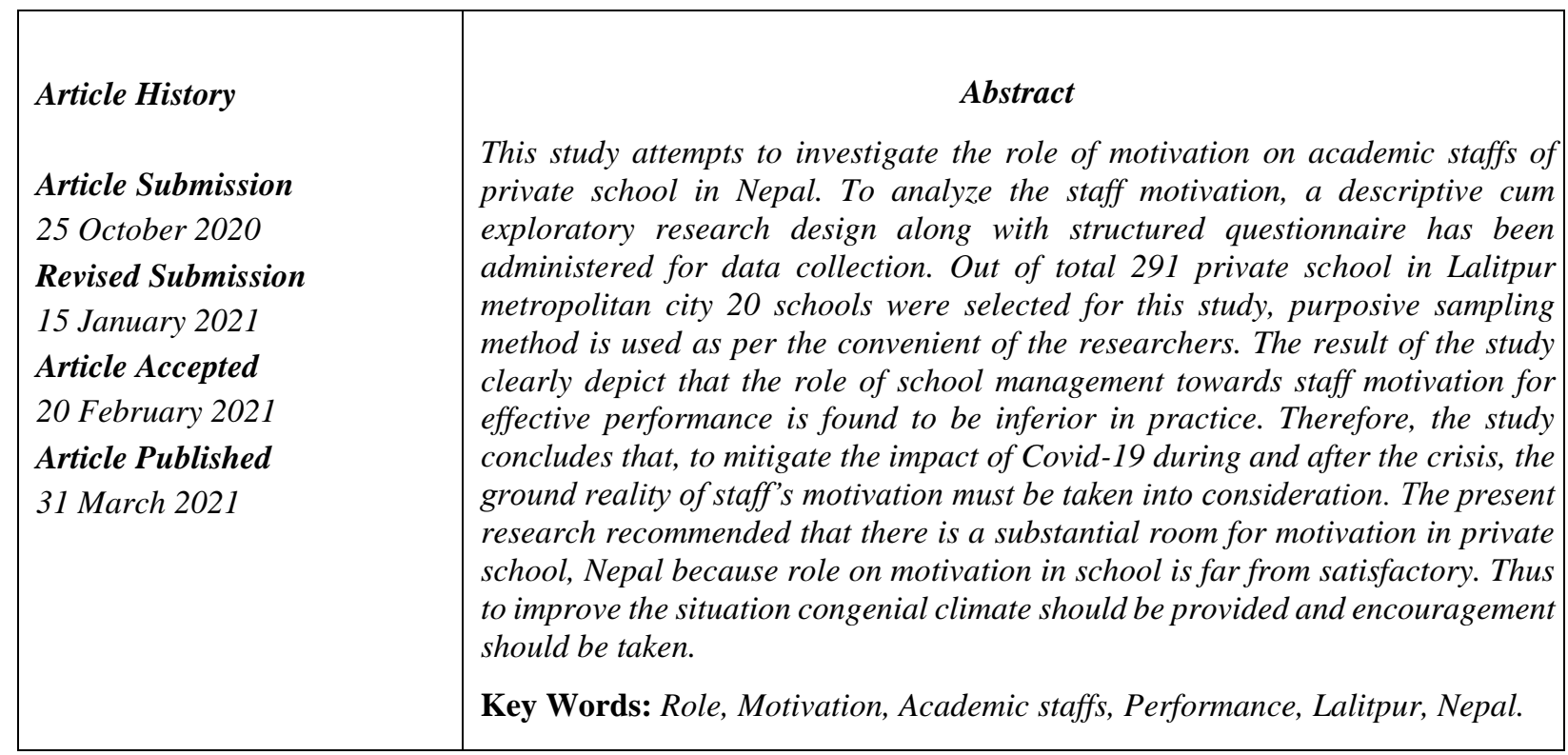

\section{Introduction}

Motivation is considered as an essential aspect of an organization that enhances employee efficiency and plays an important role in establishing the healthy working environment. The rational motivation leads towards the achievement of an organizational goal. Employee motivation could be intrinsic and extrinsic (Armstrong, 2001). Irrespective of an organization being public or private, the organizational spirit arrives from the degree of motivational tools applied within the system. (Lewis et al, 1995; Rovins and Decenzo, 2008; Locke et al, 1988). Meanwhile, an ensuring workplace motivation is one of the important functions of managers (Petcharak, 2002; Cheng, 1995; Roberts, 2005). This indicates that the employee motivation in terms of their enthusiastic and positive behavior towards work is crucial for the survival and growth of an organization. Katzell and Thompson (1990) affirm that a happy worker is good worker. Various organizational psychologist and management experts have been engaged in a vigorous debate regarding the relationship between motivation and employees job performance (Buchanan, 2006). Moreover, Nnkko (2010) also reflected the importance of motivation among academic employees in the process of harnessing the performance.

The motivation of a person is determined by his behavior and the desired moves (Mifflin, 1995). Hence, it can be considered as "Willingness to exert high level of inspiration to reach organizational goals, conditioned by the efforts ability to satisfy some individual need (Robins and Coulter, 2005). Even in the process of job retention, motivation has its own essence and also deemed as a common element between job retention and job performance of employees (Tealdi, 2005). Employee motivation is one of the most important management functions that brings the highest potential when it comes to utilizing their abilities to achieve the best performance. (Dell, 2019). An employee performance towards the achievement of organizational goals basically depends on the different stage and nature of the job (Prasad and Vaidya, 2020). Individual's knowledge, skills, abilities and personal needs which are 
inherent essentials to perform given task efficiently determines the individual's and organizational performance.

Based on the literature related to motivation and its factors, it can be noticed that motivation does not only encourage for efficient performance but also shows the organizational practice on employee welfare. Therefore, the purpose of this paper is to investigate the staff motivation strategies practiced by private schools of Lalitpur, Nepal.

\section{Objectives of the study:}

Covid-19 pandemic which was originated from Wuhan, China has changed the reality of the globe. It has unsettled the various sectors of the economy along with the human life (Ellit, 2020; Harowit, 2020). The world could see the paramount economic and development crisis during mid 1900s after the World War II. Hence, such crisis would generally lead towards various institutional catastrophe. With this reference, the impact of the ongoing pandemic in the academic institution without an exception of school level education is also an inevitable phenomenon. Education sector is one of the majorly affected fraternity in the world. In the Nepalese context too, this community has seen severe predicament. In this regards, Buckler et al; (2020) pointed out that school staffs go through an immense pressure regarding their academic career. School employees including teachers also have to reconsider all their working approaches and keep themselves updated with the unprecedented system. Phuyal (2020) argues that teachers are forced to do the job without proper planning and training. Therefore, the present scenario in Nepal raises several questions regarding the approaches of schools considering the orientation of online pedagogy to the teachers. Whether teachers and staffs are able to run online function properly. The need assessment of online learning training. Do all academic staffs have access to smart digital devices? And many more about job security, digital communication, payment mode, and a like.

With all these negativity among the academic staffs due to the presence of the Covid-19, it is right time for school authority to motivate and create an environment for its employees to overcome the challenges put forward by such adverse scenario.

The major concern in every type of service organization is the motivation of their employees irrespective of their level of skill and mode of work. In crisis environment, motivation is even more indispensable part of an organization (Kuchava and Buchashvili, 2016). In an educational institution, academic staff motivation is an essence in determining the quality interface. Nepal has been facing country wise lockdown and curfew since March 2020. UNESCO estimates that about nine million students are affected in Nepal due to academic institution closer due to covid-19 (Dawadi et al; 2020). Therefore, the present research paper highlights some of the challenges faced by Nepalese academic institutions and investigates some strategies to nullify the impact of the Covid-19 through staff motivation. Due to this pandemic, the school system has not been able to operate physically. The entire system of education has changed dramatically, with the distinctive use of remote teaching learning mode via online and digital platform. However, there is a lack of research leading towards the investigation in the staff motivation in the present context of Nepal. Similarly, the need of clarification in terms of the staff motivation in private schools in Lalitpur, Nepal is increasing. Hence, this study intends to mitigate the gap prevailed in this aspect.

\section{Methodology:}

This research used a combination of quantitative and qualitative research design to explore employee motivation issues in schools of Lalitpur Metropolitan city. Data were collected through both primary sources and secondary source. The primary data is collected through field survey, questionnaire and interview schedule whereas; secondary data is gathered through content analysis. Out of total 291 (Numbers according to Education in Figures 2017; Published by Ministry of Education Science \& Technology) private schools in Lalitpur Metropolitan city 20 schools were selected as sample for the study. Purposive sampling method is used as per the convenient of the researcher. Study variables for this study are chosen with reference of the theory of motivation published by Maslow (1943) and Herzberg (1959) along it also taken help form the studies of Aryan and Singh (2015); Ekundayo (2018) for selecting study variables. A sum of 225 questionnaire was sent to the teachers/employees working at different level in sampled schools out of which 218 questionnaires were returned with a response rate of $96.89 \%$ out of them 214 questionnaire forms were properly completed and used for analysis. A 
fourpoint Likert scale ranging from Strongly agree -(4), Agree - (3), Disagree - (2), and Strongly disagree - (1) was used to measure the adequacy of the data. Regression analysis, correlation analysis, descriptive statistics, frequency tables and percentages were used for data presentation and Chronbach's Alpha of all items have been used for reliability test. The collected data were processed in Ms-exel and SPSS version 23. The values of Cronbach's Alpha are presented in table 1.

Table 1: Reliability Statistics

\begin{tabular}{|l|c|c|}
\hline Statements & Cronbach's Alpha & No. of Items \\
\hline $\begin{array}{l}\text { Factors of motivation in private schools in Lalitpur } \\
\text { metropolitan city }\end{array}$ & 0.87 & 12 \\
\hline
\end{tabular}

Source: SPSS output

The value of Cronbach's Alpha is 0.87 for statements of factors of motivation in private schools in Lalitpur metropolitan city, which are all together 12 items. It is considered acceptable when the coefficient is greater or equal to 0.70 and is a good indication of construct reliability (Nunnally, 1978). Similarly, the result shows that the acquired values of Alpha are greater than 0.70, which suggested that all items related to the construct are reliable and acceptable.

\section{Result and Analysis}

In this section, the acquired data are presented in tables and figure to keep the study concise and easy to understand, and to simplify the analysis process. For the perceptual analysis of data, the following section presents the employees status of motivation with their job, preference and suggestions for different factors of motivation in schools of Lalitpur metropolitan city.

Table 2: Profile of respondents

\begin{tabular}{|c|c|c|c|c|c|c|}
\hline \multirow[t]{2}{*}{ Work Experience } & \multicolumn{4}{|c|}{$\mathrm{G}$ ender of the Respondents } & \multirow[t]{2}{*}{ Total } & \multirow[t]{2}{*}{$\%$} \\
\hline & Male & $\%$ & Female & $\%$ & & \\
\hline Less than one year & 17 & 7.95 & 6 & 2.80 & 23 & 10.75 \\
\hline $2-5$ year & 50 & 23.36 & 64 & 29.90 & 114 & 53.27 \\
\hline 6-10 year & 15 & 7.00 & 22 & 10.29 & 37 & 17.28 \\
\hline $11-15$ year & 12 & 5.60 & 17 & 7.95 & 29 & 13.56 \\
\hline Above 15 year & 4 & 1.87 & 7 & 3.28 & 11 & 5.14 \\
\hline Total & 98 & 45.78 & 116 & 54.22 & 214 & 100 \\
\hline
\end{tabular}

Source: Survey, 2020

Table 2 shows the general profile of the respondents where $45.78 \%$ respondents are male and $54.22 \%$ respondents are female. Table also shows that $10.75 \%$ employees have less than oneyear work experience whereas; $53.27 \%$ employees have 2-5-year work experience, $17.28 \%$ employees have 6-10year work experience, $13.56 \%$ employees have 11-15-year work experience and $5.14 \%$ employees has more than 15-year work experience. The table also indicate that private schools have the higher numbers if female employees with higher work experience in compare with male employees. The table indicate that most of respondents stick with same institution for 2-5 years then they either change their organization after having some job experience or shift their job sector. 
Table 3: Preference towards Monetary vs. Non-monetary Incentives

\begin{tabular}{|l|c|c|}
\hline \multicolumn{1}{|c|}{ Incentives } & Frequency & Percentage (\%) \\
\hline Monetary & 84 & 39.25 \\
\hline Non-monetary & 75 & 35.05 \\
\hline Both Total & 55 & 25.70 \\
\hline \multicolumn{2}{|c|}{ Tor } & 100 \\
\hline
\end{tabular}

Source: Survey, 2020

Table 3 shows that respondent's preference between monetary and non-monetary incentives. It is seen that $39.25 \%$ respondents were prefer monetary incentives which indicates that they like to enjoy with handsome salary and bonus from their jobs. Whereas; $35.05 \%$ respondents were happy to enjoy with non-monetary incentives which implies that they like to enjoy with different fringe benefits while $25.70 \%$ respondents prefer both monetary and non-monetary incentives to motivate them. The table indicate that both monetary and non-monetary incentives are equally important to motivate the employees towards their jobs.

Table 4: Descriptive Statistics on Preference among Different Motivational Factors

\begin{tabular}{|l|l|l|l|l|l|}
\hline S.N. & Statements & Minimum & Maximum & $\begin{array}{l}\text { Mean } \\
(\mathbf{M})\end{array}$ & $\begin{array}{l}\text { Std. } \\
\text { Deviation } \\
\text { (SD) }\end{array}$ \\
\hline 1. & $\begin{array}{l}\text { Wages and salaries as a factor of } \\
\text { motivation }\end{array}$ & 1 & 4 & 3.34 & 0.841 \\
\hline 2. & Fringe Benefits as Factor of Motivation & 1 & 4 & 3.08 & 0.927 \\
\hline 3. & $\begin{array}{l}\text { Training of Workers as Factor of } \\
\text { Motivation }\end{array}$ & 1 & 4 & 2.95 & 0.882 \\
\hline 4. & $\begin{array}{l}\text { Participation in Decision Making as } \\
\text { Factor of Motivation }\end{array}$ & 1 & 4 & 2.76 & 1.093 \\
\hline 5. & Promotion as Factor of Motivation & 1 & 4 & 2.64 & 1.146 \\
\hline 6. & $\begin{array}{l}\text { Working Conditions as a Factor of } \\
\text { Motivation }\end{array}$ & 1 & 4 & 2.42 & 1.027 \\
\hline 7. & $\begin{array}{l}\text { Freedom/flexibility to Work as Factor } \\
\text { of Motivation }\end{array}$ & 1 & 4 & 3.02 & 0.517 \\
\hline 8. & Recognition as Factor of Motivation & 1 & 4 & 2.76 & 0.793 \\
\hline 9. & Job Security as Factor of Motivation & 1 & 4 & 2.91 & 0.813 \\
\hline 10. & $\begin{array}{l}\text { Personal Growth Opportunity as Factor } \\
\text { of Motivation }\end{array}$ & 1 & 4 & 3.23 & 1.068 \\
\hline 11. & Peers Relation as factor of Motivation & 1 & 4 & 2.64 & 0.948 \\
\hline 12. & $\begin{array}{l}\text { Retirement Benefits as factor of } \\
\text { Motivation }\end{array}$ & 1 & 4 & 3.13 & 0.819 \\
\hline
\end{tabular}

Source: Survey, 2020

Table 4 shows that descriptive analysis of data based on response from 214 academic staffs about their preference among different factors of motivation. It shows that maximum respondents $(\mathrm{M}=3.34$ out of total Likert rating scale 4 to 1 ) believed that wages and salaries as one of the major motivational factors for employees towards their job and one of the major components of motivational strategy of the organization. Table also indicate that majority $(\mathrm{M}=3.08)$ respondents strongly agreed that along with wages and salaries other fringe benefits are equally important to motivate the employees. The table indicate that agreed $(M=2.95)$ view on proper training as per changing forces of the internal and external 
environment which can help them to work efficiently in that changing environment is motivating to employees. The table also shows that average agreement ( $M=2.76,2.64$ and 2.42) that participation in decision making, promotion and working condition are motivating factor towards their job where variations ( $\mathrm{SD}=1.093,1.146$ and 1.027) are seen in responses of respondents which indicate that some of the respondents highly rated these factors but some of them lower rated. Table reveal that freedom/flexibility in work is one of the important factor of motivation which is equally valued among the respondents with lowest variation $(\mathrm{SD}=0.517)$ in response for other factor which indicate that almost all $(M=3.02)$ employees need some degree of freedom and flexibility in their work that allows them to work from home and flexible working time in difficult situation as global pandemic covid-19 created all over the world. The table present that respondents are agreed $(\mathrm{M}=2.76$ and 2.91) that employee's recognition in work place in front of other management and colleague and secured nature of job that how much their jobs are secured in different time period in different conditions specially like present scenario where may peoples are losing their job due to difficult situation created by covid-19, a secure nature of job can play a greater role to motivate the employees. The table convey that personal growth opportunity for the employees in job is highly agreed $(M=3.23)$ motivating factor among the respondents which indicate that each employee seeks for their career growth opportunity though some respondents has varied $(\mathrm{SD}=1.068)$ and different in their opinions and not given much value for this factor. The table also shows that respondents are agreed $(\mathrm{M}=2.64)$ that employee's good relation with their colleague or peer group is motivating for them and they believed that they friendly environment in their work place. The table also present that respondents are mostly agreed $(\mathrm{M}=3.13)$ on retirement benefits are one of the important motivating factors which indicate that retirement policies, pensions, gratuity etc. facilities are highly motivating for their jobs.

\section{Figure 1: Satisfaction Level with Current Motivational Schemes}

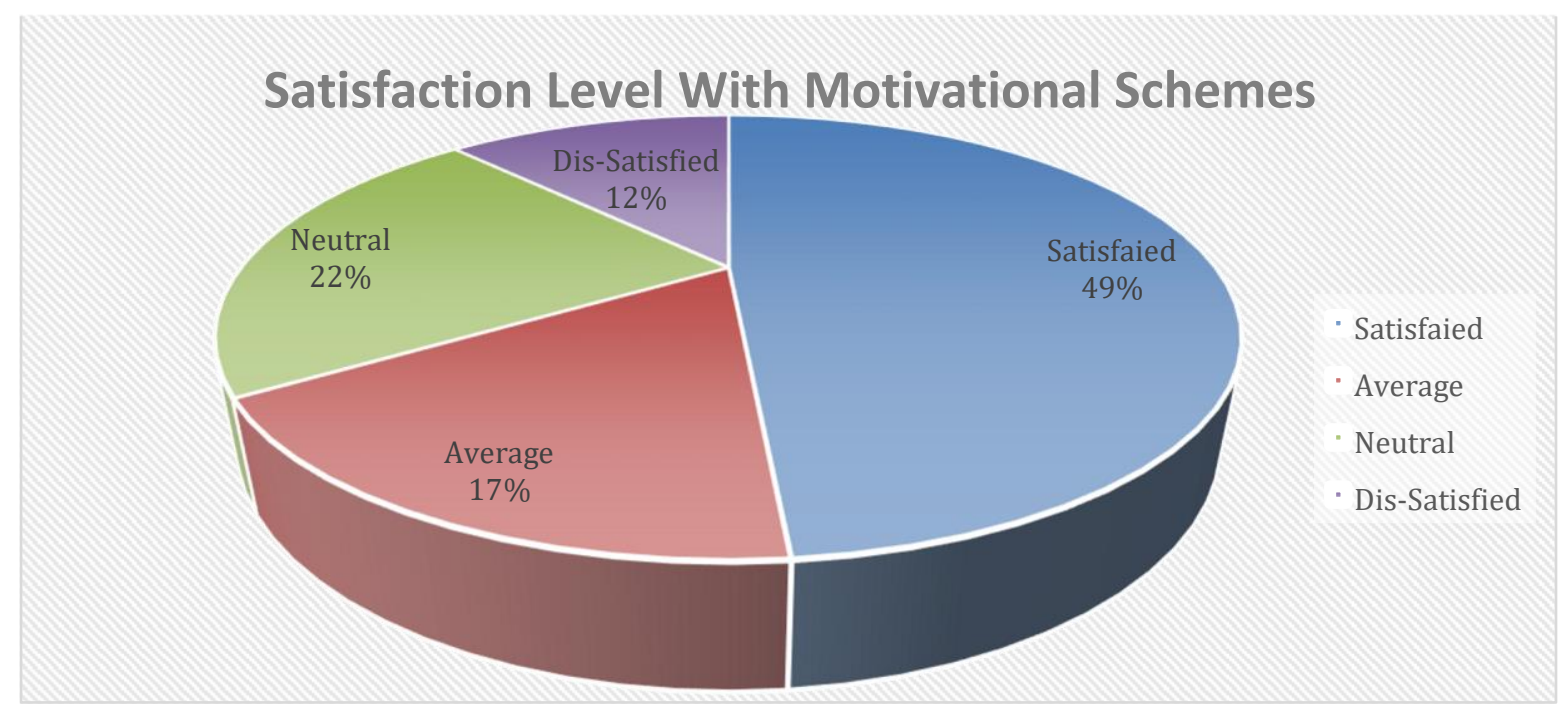

Source: Survey,2020

Figure 1 shows that among 214 respondents nearly half (49\%) of the respondents are satisfied with existing motivational schemes and strategies adopted by their respective organization whereas $17 \%$ of the employees thinks that motivational schemes and strategies adopted by their organization is neither good nor bad but its average satisfactory.

The figure also shows that $22 \%$ respondents are do not want to say anything regarding effectiveness of motivational schemes and strategies adopted by their organization. Whereas $12 \%$ respondents were thinking that motivational schemes and strategies adopted by their institutions are not well enough. Piechart also indicated that majority of the respondents are satisfied with motivational practices, strategies and policies adopted by their respective institutions. 
Table 5: Suggested Motivational Tools

\begin{tabular}{|l|c|c|}
\hline \multicolumn{1}{|c|}{ Suggested Motivational Tools } & Frequency & Percentage (\%) \\
\hline Promotion on the basis of experience/performance & 67 & 31.3 \\
\hline Promoting employee's potentials & 41 & 19.1 \\
\hline Job Status & 35 & 16.4 \\
\hline Performance based rewards & 33 & 15.4 \\
\hline Advancement on the job & 21 & 9.8 \\
\hline Goal clarity on the job Total & 17 & 8.0 \\
\hline \multicolumn{1}{|c|}{ Tob } & 214 & 100 \\
\hline
\end{tabular}

Source: Survey, 2020

Table 5 shows that different motivational tools suggested by the 214 respondents of the study for motivating the employees towards their jobs. Table shows that $31.3 \%$ respondents suggested that employees' promotion based on their experience /performance can motivate employee towards their job which gives them job satisfaction believing that their work experience and hard work for better performance worthy for organization. Whereas $19.1 \%$ respondents suggested that promoting and encouraging the potentials of employees can motivate the employees towards their job and institutions by increasing feelings of belongingness towards their job.

Table also shows that $16.4 \%$ respondents suggested that the status of job and its reputation in the society can also motivate employee to stick with their existing job whereas $15.4 \%$ respondents suggested that employee's rewards based on their performance without any biasness motivate and encourage to carry on better performance in the organization.

Table shows that $9.8 \%$ respondents suggested that advancement in the job with new technologies and modern concept of management also motivate employees toward=s their jobs which make them feel that they in the such organization which always work with modern technologies which enhances their productivity and also following the modern principles of the management. Table also shows that $8 \%$ respondents suggested that clear goal of their job and effective communication with management regarding their goal of job is also motivating for employees.

Table 6: Correlations among Factors of Motivation

\begin{tabular}{|c|c|c|c|c|c|c|c|c|c|c|c|c|}
\hline Variables & $\begin{array}{l}\text { Wag } \\
\text { es and } \\
\text { salari } \\
\text { es }\end{array}$ & \begin{tabular}{|l|} 
Fring \\
e \\
benef \\
its \\
\end{tabular} & $\begin{array}{l}\text { Traini } \\
\text { ng }\end{array}$ & $\begin{array}{l}\text { Participa } \\
\text { tion }\end{array}$ & $\begin{array}{l}\text { Promot } \\
\text { ion }\end{array}$ & $\begin{array}{l}\text { Worki } \\
\text { ng } \\
\text { condit } \\
\text { ion }\end{array}$ & $\begin{array}{l}\text { Freedo } \\
\text { m/ } \\
\text { flexibi } \\
\text { lity }\end{array}$ & $\begin{array}{l}\text { Recogni } \\
\text { tion }\end{array}$ & $\begin{array}{l}\text { iJob } \\
\text { secur } \\
\text { ity }\end{array}$ & $\begin{array}{l}\text { Perso } \\
\text { nal } \\
\text { growt } \\
\text { h } \\
\end{array}$ & $\begin{array}{l}\text { Peers } \\
\text { relati } \\
\text { on }\end{array}$ & \begin{tabular}{|l|} 
Retirem \\
ent \\
benefit
\end{tabular} \\
\hline $\begin{array}{l}\text { Wages and } \\
\text { salaries }\end{array}$ & 1 & & & & & & & & & & & \\
\hline \begin{tabular}{|l} 
Fringe \\
benefits
\end{tabular} & $.017^{*}$ & 1 & & & & & & & & & & \\
\hline Training & $.217^{*}$ & $.139^{*}$ & 1 & & & & & & & & & \\
\hline Participation & $.024^{*}$ & $.392^{*}$ & $.019^{*}$ & 1 & & & & & & & & \\
\hline Promotion & $.303^{*}$ & $.028^{*}$ & $.660^{* *}$ & $\begin{array}{l}.320^{*} \\
*\end{array}$ & 1 & & & & & & & \\
\hline $\begin{array}{l}\text { Working } \\
\text { Conditions }\end{array}$ & $.332^{*}$ & .395 & $.385^{*}$ & $.335^{*}$ & $.215 *$ & 1 & & & & & & \\
\hline $\begin{array}{l}\text { Freedom/flex } \\
\text { ibility }\end{array}$ & \begin{tabular}{|l}
$\mathrm{x}$ \\
\end{tabular} & $.251^{*}$ & $.076^{*}$ & $.160^{*}$ & .108 & $.648^{*}$ & 1 & & & & & \\
\hline
\end{tabular}




\begin{tabular}{|l|c|l|l|l|l|l|l|l|l|l|l|l|}
\hline Recognition & $.079^{*}$ & $.204^{*}$ & $.133^{*}$ & $.212^{*}$ & $\begin{array}{l}.223 \\
*\end{array}$ & $.245^{*}$ & $.378^{* *}$ & 1 & & & & \\
\hline Job Security & $.088^{*}$ & $.248^{*}$ & $.150^{*}$ & $.340^{*}$ & $\begin{array}{l}.229 \\
*\end{array}$ & $.370^{* *}$ & $.316^{* *}$ & $.333^{* *}$ & 1 & & & \\
\hline $\begin{array}{l}\text { Personal } \\
\text { Growth }\end{array}$ & .144 & $.248^{*}$ & $.524^{* *}$ & $.624^{* *}$ & $.505^{*}$ & $.109^{*}$ & $.205^{*}$ & .131 & .248 & 1 & & \\
\hline $\begin{array}{l}\text { Peers } \\
\text { Relation }\end{array}$ & $.217^{*}$ & .033 & $.378^{*}$ & $.216^{*}$ & $\begin{array}{l}.131 \\
*\end{array}$ & $.548^{*}$ & $.109^{*}$ & $.148^{*}$ & .271 & $.436^{* *}$ & 1 & \\
\hline $\begin{array}{l}\text { Retirement } \\
\text { Benefits }\end{array}$ & $.257^{*}$ & .078 & $.241^{*}$ & $\begin{array}{l}.333^{*} \\
*\end{array}$ & .032 & $.397^{* *}$ & $.473^{* *}$ & $.274^{* *}$ & $.550^{*}$ & $.303^{* *}$ & $363^{* * *}$ & 1 \\
\hline
\end{tabular}

Source: SPSS output

Note:

**. Correlation is significant at the 0.01 level (2-

tailed). *. Correlation is significant at the 0.05 level

(2-tailed).

The above correlation table is showing the interdependency of various factors of motivation. Promotional opportunities are correlated to training to the extent of $66 \%$. Table explain that working condition is $64.8 \%$ corelated with freedom and flexibility in work. Schools' employees see their personal growth if they get proper job-related trainings $(r=0.524)$ and participation on decision making which improve their managerial skills $(\mathrm{r}=0.624)$. Table also indicate that their personal growth is also $50.5 \%$ correlated with their promotions. Working condition is $54.8 \%$ correlated to peer's relation of employees. Job security is also showing $55 \%$ of relation with retirement benefits of the employees. Employees' training is a variable which is highly correlated with promotion of employees.

\section{Regression analysis on the effect of financial and non-financial rewards on motivation of academic staffs:}

The regression analysis was conducted to find, how financial and non-financial rewards affected motivation of academic staffs of private schools of Lalitpur metropolitan city. The respondent's overall mean score on motivation was considered as the dependent variable and financial and non-financial rewards as the independent variables. Thus, mean aggregate scores for respondents' opinion on financial and non-financial rewards were regressed on the overall score for motivation. The beta coefficients provided the relative importance of various rewards. The highest beta coefficient value of rewards was expected to have highest influence on motivation, while the lower beta coefficient stands second in terms of relative significance and so on. The Regression results are shown in tables below.

Table 7: Summary of Regression model

\begin{tabular}{|c|c|c|c|c|c|c|}
\hline \multirow{3}{*}{\multicolumn{2}{|c|}{ Model }} & $\mathrm{R}$ & R Square & $\begin{array}{c}\text { Adjusted R } \\
\text { Square }\end{array}$ & \multicolumn{2}{|c|}{$\begin{array}{l}\text { Std. Error of the } \\
\text { Estimate }\end{array}$} \\
\hline & & $0.878^{\mathrm{a}}$ & .760 & 0.745 & \multicolumn{2}{|c|}{1.12412} \\
\hline & & $\begin{array}{l}\text { Sum of } \\
\text { Squares }\end{array}$ & Df & Mean Square & $\mathrm{F}$ & Sig. \\
\hline \multirow{3}{*}{1} & Regression & 204.759 & 1 & 204.759 & 156.17 & 0.000 \\
\hline & Residual & 55.983 & 41 & 1.216 & & \\
\hline & Total & 260.742 & 42 & & & \\
\hline
\end{tabular}

a. Dependent variable: Motivation.

b. Predictors: financial and non-financial rewards.

The study used F-statistics to establish the appropriateness of the regression model to give reliable results. F- significance value of $\mathrm{p}=0.000$ was established. This shows that the regression model has a less than 0.001 likelihood (probability) of giving a wrong prediction. 
The table shows that the value of co-efficient of determination (adjusted R square) is 0.745 for all the variables studied (financial and non-financial rewards). This implies that there was a variation of $74.5 \%$ between the independent variable (financial and non-financial rewards) and dependent variable (motivation of academic staffs). Thus, it means that financial and nonfinancial rewards explained $74.5 \%$ of the motivation of academic staffs of private schools of Lalitpur metropolitan city.

\section{Table 8: Regression Coefficients}

\begin{tabular}{|c|c|c|c|c|c|c|}
\hline \multirow{2}{*}{\multicolumn{2}{|c|}{ Model }} & \multicolumn{2}{|c|}{$\begin{array}{c}\text { Unstandardized } \\
\text { Coefficients }\end{array}$} & \multirow{2}{*}{\begin{tabular}{|c|}
$\begin{array}{l}\text { Standardized } \\
\text { Coefficients }\end{array}$ \\
Beta
\end{tabular}} & \multirow[b]{2}{*}{$\mathrm{T}$} & \multirow[b]{2}{*}{ Sig. } \\
\hline & & B & Std. Error & & & \\
\hline \multirow[t]{3}{*}{1} & (Constant) & 10.432 & 1.622 & & 5.143 & 0.000 \\
\hline & Financial Rewards & 0.455 & 0.35 & .513 & 10.624 & .010 \\
\hline & Non-financial Rewards & 0.412 & 0.014 & .005 & 0.107 & 0.021 \\
\hline
\end{tabular}

a. Dependent Variable: Motivation

The study results show that there was a positive relationship between rewards and motivation of academic staffs in private schools of Lalitpur metropolitan city. The un-standardized regression coefficients show, how every metric unit change in the independent variable, the dependent variable changes by $\mathrm{x}$ units. This implies that a unit increase in financial rewards would lead to a unit increase in motivation of academic staffs in private schools of Lalitpur metropolitan city at a factor of 0.455 . A unit increase in non-financial reward would influence motivation of academic staffs in private schools of Lalitpur metropolitan city by a unit of 0.412 . The results further show that there is a significant relationship between motivation of academic staffs in private schools of Lalitpur metropolitan city and the two variables (financial and nonfinancial rewards), as shown by the $p$ value; $(p=0.000<0.05)$. The equation $\mathrm{Y}=10.432+0.455 \mathrm{X} 1+0.412 \mathrm{X} 2$.

\section{Discussion and Conclusions}

There is no denying the fact that the role of motivation on academic staffs has undoubtedly become an important area of the study after Covid-19 Pandemic spread Globally. The spread of pandemic has significantly interrupted every sectors and aspects of life including education sector. This paper has provided a ground reality of the state of motivation on academic staffs

i.e. (admin and teaching staffs) during the pandemic. As far as the perception of the staffs is concerned, it is found that both financial and non- financial rewards and incentives are equally important to motivate staffs towards their job despite of slightly higher influence of financial rewards on motivation of academic staffs were seen in Nepal. Motivation could be both intrinsic and extrinsic and are equally important in harnessing effective performance (Afful-

Broni, 2004; Mankoe, 2006; Gupta, 2008). The academic staffs seem to have high expectation from the school management in terms of trainings and motivation during crisis. However, the role of school management towards staff motivation for effective performance is found to be inferior in practice. For this, Buberwa (2015) argues that an employee may underperform when they are not getting satisfied with the current practice of motivation. Therefore, the study concludes that, to mitigate the impact of Covid-19 during and after the crisis, the ground reality of staff's motivation must be taken into consideration. This will have a positive reflection on the performance for long run survival and growth of particular schools in Nepal. In addition, the present research further reveals that staff's perceptions of their training programs in the school are inadequate and less satisfactory. Similarly, flexibility of work, recognition, promotion and participation in decision making in schools are far below the expectation. In regards to the service sectors in Nepal, there is a number of performance related problems being faced by Nepalese organization. The presence of weak corporate culture, weak enforcement of rules and regulations, operational inefficiencies, growing employee dissatisfaction and lack of work motivation is seen in regular scale (Adhikari, 2009; Economic survey, 2006, 2007).

Furthermore, according to survey carried out by (CRANET Nepal, 2005), the money spent by employers on trainings and development is very low in proportion to the annual salary paid to the employees. In this regard, Adhikari (2010) exposed that the ratio of payroll to training cost per 
organization is near to $0.5 \%$ in Nepal, as compared to $1.5 \%$ in India and $3.1 \%$ in the UK (Adhikari, 2004). Training in Nepal is considered as the compliance of the rule rather than the needs of the employees (Chaudhary, 2014).

Likewise, the sense of job security among academic staffs is very questionable in private schools of Nepal, which indicates the presence of high turnover rate. This situation has raised several questions to the school authority regarding the staff welfare. This has resulted into an underperformance and lack of utilization of full potential among the academic employees. The underprepared staffs will have an negative impact on the quality of the school education programs (Dawadi et al, 2020; Phuyal, 2020; Pudasaini, 2020). So, this study concludes that the school management including local government should motivate school staffs in this critical situation through strengthening their capacity to do work efficiently. Further, the ongoing Covid-19 pandemic has created an environment of educational mobocracy. Hence, the proper action plan strategy for staff motivation are needed to be timely addressed. Noncompliance of this would impair the good image of private schools in Lalitpur, Nepal in future. Moreover, the researcher recommended that, the remote working option along with job security and trainings needs to be worked out by the school authority in order to reduce the fear of job and career well beings. Thus, the knowledge generated through this study can be useful to future researcher and concerned authority for their future concerned strategies. This study will be significant to academic institutions in providing a basis for policy making, and offering direction for management of these institutions, researchers and academicians. Academic institutions may use the findings of the study in designing proper motivational schemes and strategies. Similarly, academicians will also find the study useful in adding to the existing literature on motivation. Finally, the study concludes that there is still a considerable room for further research and further improvements since, the practice of financial and non- financial aspects of motivation is not adequate in private schools in Nepal. In addition, the study has identified and analysed several motivational factors related to the academic staffs in the context of private schools of Lalitpur, Nepal.

\section{References}

[1]. Agwu, M. (2013). Impact of Fair Reward System on Employees Job Performance in Nigerian Agip Oil Company Limited Port-Harcourt. BJESBS, Vol. 3, No.1, pp.47-64.

[2]. Akintoye, I.R. (2000), The place of financial management in personnel psychology. A Paper Presented as Part of Personnel Psychology Guest Lecture Series, Department of Guidance and Counselling, University of Ibadan, Nigeria

[3]. Allender S., Cowburn G., and Foser, E. (2006), Understanding Participation in Sports and Physical Activity Among Children Adults, pp. 826-836.

[4]. Alumode, B. E. (2005), Enrolment Patterns and Teacher's Adequacy in Ebonyi State Secondary School. An unpublished Ph.D thesis. Department of Educational Foundations, faculty of Education. Ebonyi State University.

[5]. Armstrong, M. (2010), Armstrong's handbook of performance management. Kogan Page Limited.

[6]. Aryan, R. and Singh, A. (2015), Impact of Motivation and Recognition on Employee's Performance: A Study on Public and Private Sector Banks in Punjab and Haryana. Global Journal of Management and Business Research: An Administration and Management, Vol. 15, No. 13, Version 1. Retrieved on July 29, 2020 from:

[7]. https://globaljournals.org/GJMBR_Volume15/1-Impact-of-Motivation-andRecognition.pdf

[8]. Azoulay, P. G., Zivin J.S. and Manso, G. (2010), Incentives and creativity: evidence from the academic life science. The Journal of Economics, Vol. 42, No. 3, pp. 527-554.

[9]. Bellenger, D.N., Wilcox, J.B. \& Ingram, T.N. (1984), “An examination of reward preferences for sales managers". Journal of Personal Selling and Sales Management, Vol.4, No. 2, pp. $1-6$. 
[10]. Broussard, S. C. \& Garrison, M. E. B. (2004), The relationship between classroom motivation and academic achievement in elementary school-aged children. Family and Consumer Sciences Research Journal, Vol. 33, No. 2, pp. 106-120.

[11]. Colquit, L.W. (2009), Organizational Behavior. New York: Mc Graw Hill

[12]. Cole, S., \& Kartini, S. (2009), Smart money: The act of education, cognitive ability, and nancial literacy on nancial market participation, Working paper no. 09-071, Harvard Business School.

[13]. Davidson, E. (2005), "Understanding and improving quality in Tanzanian primary schooling", $\mathrm{PhD}$ dissertation, University of East Anglia, Norwich.

[14]. Dell, M. (2019), Impact of BYOD on organizational commitment: An empirical investigation, information technology and people, Vol. 32, No.2, pp. 246-268.

[15]. Retrieved from: https:// www.deepdyve.com/lp/emerald -publishing/impact-ofbyod-onorganizational-commitment-an-empirical-investigation

[16]. Dewhurst, M., Guthridge, M. and Mohr, E. (2009), Motivating people: Getting beyond money, McKinsey\& Company quarterly.

[17]. Doyle, G.T. and Forsyth, R.A. (1973), The relationship between teacher and student anxiety levels", Psychology in the Schools, Vol. 10, No. 1, pp. 231-233.

[18]. Ekundayo, O.A. (2018), The Impact of Motivation on Employee Performance in

Selected Insurance Companies in Nigeria. International Journal of African Development, Vol.5, No.1. Retrieved on July 29, 2020 From: https://scholarworks. wmich.edu/cgi/viewcontent.cgi?article=1087\&context=ijad

[19]. Filak, V.F. (2003), "Student psychological need satisfaction and college teacher-course evaluations", Educational Psychology, Vol. 23 No. 3, pp. 235-247.

[20]. Griffin, R.W. (2000), Management (5th edition). Delhi. AITBS Publisher and Distributors.

[21]. Goodman, V.B. (1980), Urban teacher stress: a critical literature review, Information Analyses, ERIC Document Reproduction Service No. ED 221 611, ERIC.

[22]. Gouws, A. (1995), Die verwantskap tussen motivering en werkstevredenheid van 'n groep inligtingspesialiste (The relationship between motivation and job satisfaction of

a group of information specialists). M. Bib. dissertation, Rand Afrikaans University, Johannesburg.

[23]. Guay, F., Chanal, J., Ratelle, C. F., Marsh, H. W., Larose, S., \& Boivin, M. (2010), Intrinsic, identified, and controlled types of motivation for school subjects in young elementary school children". British Journal of Educational Psychology, Vol. 80, No. 4, pp. 711-735.

[24]. Head, G. M. \& Griffin, R. W. (2009), Managing people and organizations. Delhi. Biztantra

[25]. Heryati, R. (2016), Why employee motivation is important and how to improve it.

[26]. Retrieved from: https://inside.6q.io/employee-motivation-important/

[27]. Herzberg, F. (1968), One More Time: How Do You Motivate Employees?. Harvard Business Review, Vol. 46, No.1, pp. 53-62.

[28]. Heslop, P., Smith, G.D., Metcalfe, C., \& Macleod, J. (2002), Change in job satisfaction and its association with self-reported stress, cardiovascular risk factors and mortality. Social Science \& Medicine, Vol. 54, pp. 1589-1599.

[29]. Kalimullah, A. R., Yaghoubi, N. M., \& Moloudi, J. (2010), Survey of Relationship between Organizational Justice and Empowerment (A Case Study). European Journal of Economics, Finance and Administrative Sciences, Vol. 24, pp. 165-171

[30]. Kallberg, A.L., B.F. Reskin, \& K. Hudson. (2000), Bad Jobs in America: Standard and Nonstandard Employment Relations and Job Quality in the United States. American Sociology Review, Vol. 65, No. 2, pp. 256-278.

[31]. Khadka, S. (2011), Employee retention in banking industry of Nepal. Singhania University, Rajasthan, India.

[32]. Koontz, H. (1990), Essentials of management. New York, NY: The Free Press.

[33]. Maslow, A. H. (1943), A Theory of Motivation. Psychological Review, Vol.50, p.p. 370-396.

[34]. Mifflin (1995), Management and Organization. South-Western Publishing Co., New York, NY.

[35]. Miner J. B. (2006), Essential theories of motivation and leadership. New Delhi, Prentice Hall of India Private Limited. 
[36]. Oldham, G.R., and Hackman, J.R. (2010), Not what it was and not what it will be: The Future of Job design research. Journal of Organizational Behavior, Vol. 31, No. 2-3, pp. 463-479.

[37]. Omebe, S.E. (2005), Guidance and Counseling: A Comprehensive Approach, EnuguNigeria: Cheston Agency Ltd.

[38]. Poudyal, S. R. and Pradhan, G. M. (2020), Foundation of Human Resource Management (4 ${ }^{\text {th }}$ ed.), Kriti Publication Pvt. Ltd., Kathmandu.

[39]. Rao, S. P. (2005), Essential of HRM \& Industrial Relationships, pp. 480 - 482.

[40]. Rasheed, M.I., Humayon, A. A., Awan, U. \& Ahmed, A. D. (2016), Factors affecting teachers' motivation, International Journal of Educational Management, Vol. 30, No.

1 pp. $101-114 . \quad$ Retrieved on July 29, 2020 from: https://www.researchgate.net/publication/287805118_Factors_affecting_teachers'_mo tivation

[41]. Reeve, J. (2001), Understanding Motivation and Emotion, (3rd ed.). Harcourt College Publishers, New York, NY, pp. 169, 182.

[42]. Ricks, B.R., Glinn, M.L. and Daughtrey, A.S. (1995), Contemporary Supervision, Managing People and Technology, McGraw-Hill Inc., New York, NY, pp. 169,182.

[43]. Riddell, A.R. (1998), Reforms of educational efficiency and quality in developing countries. An Overview, Vol. 28 No. 3, pp. 277-291.

[44]. Rizwan et. al. (2010), Effect of Work Motivation on Job Satisfaction in Mobile Telecommunication Service Organization of Pakistan. International Journal of Business and Management, Vol.5, No.11, pp. 213.

[45]. Robins, S.P. and Coulter, M. (2005), Management, International (7th ed.). A Pearson Education Company, Upper Saddle River, NJ, p. 424.

[46]. Schulze, S. \& Steyn, T. (2003), Educator's motivation: differences related to gender, age and experience. Acta Academia, Vol. 35, No. 3, pp. 138-160.

[47]. Shadare, O.H. (2009), Influence of Work Motivation Leadership Effectiveness and Time Management of Employees: Performance in some Selected Industries in Ibadan. Journal of Economics Finance and Administrative Science, No.16, pp. 7-17.

[48]. Shahjadi, I., Javed, A., Pirzada, S. S., Nasreen, S. \& Khanam, F. (2014), Impact of Employee Motivation on Employee Performance. European Journal of Business and

Management, Vol.6, No.23. Retrieved on July 30, 2020 from: https://www.academia.edu/31654551/Impact_of_Employee_Motivation_on_Employee_Perfo rmance

[49]. Shanks, N.H., Chapter 2: Management and Motivation [WWW page] URL: www.jblearning.com/catalog/samplefile.aspx ?isbn=076373473X\&filename $=3473 X_{-}$ CH02_4759

[50]. Spector, P.E. (2003), Industrial and organizational psychology - Research and practice (3rd ed.). New York: John Wiley \& Sons, Inc.

[51]. Stanton, H.E. (1974), The relationship between teachers' anxiety level and the test anxiety level of their students, Psychology in the Schools, Vol. 11, No. 3, pp. 360-363.

[52]. Surbhi, S. (2012), Effect of Motivation on employee performance and Organizational Productivity. Journal of Applied Management \& Computer Science, Vol1.

[53]. Tealdi, L.B. (2005), Motivation and retention of young workforce in the E\&P industry, IPTC 10884 presented at the International Petroleum Technology Conference, Doha.

[54]. Wagar, T.H. (1998), Determinants of human resource management practices in small firms: some evidence from Atlantic Canada, Journal of Small Business Management, Vol. 36, No. 2, pp. 13-23.

[55]. William, A.N. (2010). Employee motivation and performance. Mikkeli University of Applied Sciences (Thesis).

[56]. Uzonna, U. R. (2013). Impact of motivation on employee performance: A case study of credit west bank Cyprus. Journal of Economics and International Finance, Vol.5, No. 5, pp.199211. Retrieved from: https://academicjournals.org/articles/j_articles/JEIF 